The Impossible Trinity: Where does India stand?

Rajeswari Sengupta

Indira Gandhi Institute of Development Research, Mumbai March 2015

http://www.igidr.ac.in/pdf/publication/WP-2015-05.pdf 


\title{
The Impossible Trinity: Where does India stand?
}

\author{
Rajeswari Sengupta \\ Indira Gandhi Institute of Development Research (IGIDR) \\ General Arun Kumar Vaidya Marg \\ Goregaon (E), Mumbai- 400065, INDIA \\ Email(corresponding author): rajeswari@igidr.ac.in
}

\begin{abstract}
The Global Financial Crisis of 2008 and the heightened macroeconomic and financial volatility that followed the crisis raised important questions about the current international financial architecture as well as about individual countries' external macroeconomic policies. Policy-makers dealing with the global crisis have been confronted with the 'impossible trinity' or the 'Trilemma', a potent paradigm of open economy macroeconomics asserting that a country may not target the exchange rate, conduct an independent monetary policy and have full financial integration, all at the same time. This issue is highly pertinent for India. A number of challenges have emanated from India's greater integration with the global financial markets during the last two decades, one of which includes managing the policy tradeoffs under the Trilemma. In this chapter, I present a comprehensive overview of a few empirical studies that have explored the issue of Trilemma in the Indian context. Based on these studies I attempt to analyze how have Indian policy makers dealt with the various trade-offs while managing the Trilemma over the last two decades.
\end{abstract}

Keywords: Impossible Trinity, Financial Integration, Currency Stabilization, International Reserves, Sterilized Intervention

JEL Code: F3, F4, F6

\section{Acknowledgements:}

Views expressed here are entirely my own and do not reflect that of my co-authors with whom I have written the papers that have been surveyed here. 


\title{
The Impossible Trinity: Where does India stand?
}

\author{
Rajeswari Sengupta \\ Indira Gandhi Institute of Development Research (IGIDR) ${ }^{1}$
}

\begin{abstract}
The Global Financial Crisis of 2008 and the heightened macroeconomic and financial volatility that followed the crisis raised important questions about the current international financial architecture as well as about individual countries' external macroeconomic policies. Policymakers dealing with the global crisis have been confronted with the 'impossible trinity' or the 'Trilemma', a potent paradigm of open economy macroeconomics asserting that a country may not target the exchange rate, conduct an independent monetary policy and have full financial integration, all at the same time. This issue is highly pertinent for India. A number of challenges have emanated from India's greater integration with the global financial markets during the last two decades, one of which includes managing the policy tradeoffs under the Trilemma. In this chapter, I present a comprehensive overview of a few empirical studies that have explored the issue of Trilemma in the Indian context. Based on these studies I attempt to analyze how have Indian policy makers dealt with the various trade-offs while managing the Trilemma over the last two decades.
\end{abstract}

JEL Classification: F3, F4, F6

Key Words: Impossible Trinity, Financial Integration, Currency Stabilization, International Reserves, Sterilized Intervention

${ }^{1}$ rajeswari.sen@gmail.com; corresponding address: Indira Gandhi Institute of Development Research, Gen. A. K. Vaidya Marg, Goregaon East, Mumbai 400 065. Views expressed here are entirely my own and do not reflect that of my co-authors with whom I have written the papers that have been surveyed here. 


\section{Introduction}

The Global Financial Crisis (GFC) of 2008 and the heightened macroeconomic and financial volatility that followed the crisis raised important questions about the current international financial architecture as well as about individual countries' external macroeconomic policies. Policy-makers dealing with the global crisis have been confronted with the 'impossible trinity' or the Trilemma, a crucial paradigm of open economy macroeconomics asserting that a country may not be able to target the exchange rate, conduct an independent monetary policy and have full financial integration, all at the same time. The fast-paced and massive financial globalization undertaken by most emerging economies over the past 20 years along with the rapid deepening of domestic and international financial markets, have significantly modified the context of the Trilemma paradigm.

The 'impossible trinity' or the Trilemma is a fundamental contribution of the MundellFleming framework. It states that policy makers in open economies often face a three-way tradeoff between the contradictory policy objectives namely, a stable exchange rate, an independent monetary policy designed to target domestic inflation and open capital markets. Confronted with this Trilemma policy makers have to choose a combination of any two objectives because all three goals can be mutually inconsistent. For instance, supposing policy makers in an economy with fixed exchange rate raise the interest rate in order to control domestic inflation-a move that also increases the difference with world interest rate. Given arbitrage in open capital markets and the underlying interest rate parity condition, such a move will attract capital inflows into the domestic economy resulting in an appreciating pressure on the fixed exchange rate. Subsequent intervention in the foreign exchange market to buy international reserves and sell domestic currency in order to maintain the fixed exchange rate in the face of the appreciation pressure will end up defeating the original objective of controlling domestic inflation. Thus while the US is an example of an economy pursuing flexible exchange rates, open capital markets and independent monetary policy, countries belonging to the Euro zone follow a combination of exchange rate stability, financial integration and zero monetary independence (Aizenman, 2010). In recent times, empirical estimation of the Trilemma has been popularized in the academic literature most notably by Obstfeld, Shambaugh and Taylor $(2005,2010)$ and Aizenman, Chinn and Ito (2008; 2010a, b; 2011). 
The issue of the Trilemma is highly pertinent for India - a major emerging economy in a world where emerging or transitioning countries are increasingly playing a crucial role in restoring global economic growth in the post-crisis era. A number of challenges have emanated from India's greater integration with the global financial markets during the last two decades, one of which includes managing the policy tradeoffs presented by the Trilemma. The importance of the Trilemma in present day macroeconomic context in India cannot be overstated. Yet there have been very few empirical studies that have investigated this issue for India. This is perhaps because for the longest of time India has followed a pegged exchange rate regime, and a relatively closed capital account compared to other emerging economies. However with the passage of time and increasing integration with the global economy, a shift away from pegged exchange rate regime and steady albeit cautious liberalization of the capital account have made the macroeconomic management of the Trilemma policy objectives increasingly complex. ${ }^{2}$

Halfway into the current decade, India is experiencing several interesting phenomena in its macroeconomic environment. Its GDP growth rate is increasing once again after few years of slowdown in the aftermath of the Global Financial Crisis; its equity and debt markets continue to attract foreign capital inflows buoyed by the economy's revitalized growth prospects and improving macroeconomic scenario; it is on the verge of embarking on a 'glide-path' of inflation targeting following the release of the Urjit Patel Committee Report by the RBI in 2014, and finally, it continues to face growing currency volatility owing to a rapidly changing post-crisis global environment. In view of these, the question of where India stands with regard to the Trilemma becomes all the more pertinent now.

In this chapter, I present a comprehensive overview of a select few empirical papers that I have written with other co-authors, investigating the evolution of the Trilemma in India over the past couple of decades and analyzing the extent of tradeoffs faced by policy makers between financial integration, monetary autonomy and exchange rate stability. Based on these studies I attempt to analyze how have Indian policy makers dealt with the various trade-offs while managing the Trilemma over the last two decades and also draw relevant policy conclusions.

\footnotetext{
${ }^{2}$ In this chapter financial integration and capital account openness have been used interchangeably to mean the integration of the domestic economy with global financial markets.
} 


\section{India post 1991 liberalization reforms}

After the Balance of Payments crisis in 1991, a comprehensive series of liberalization, privatization and deregulation reforms were implemented in the banking sector, trade sector as well as financial markets in India, the net result being, over the next couple of decades the Indian economy witnessed several structural changes (Shah, 2008; Mohan and Kapur, 2009; Hutchison, Sengupta, Singh, 2011). In what follows, I provide a brief account of the Indian economy with respect to the two main tenets of the Trilemma-capital account openness and exchange rate stability.

\subsection{Capital Account Management}

India's capital account liberalization that began in early 1990s has since then been a steady albeit slow and gradual process (Hutchison, Kendall, Pasricha and Singh, 2010; Sen Gupta and Sengupta, 2014). As regards opening up the financial markets to foreign investment, Indian authorities have always proceeded with a lot of caution and apparent skepticism about the benefits of foreign capital balanced against the potential instability that such capital inflows might trigger. While on one hand foreign capital offers diversification opportunities to investors and provides avenues to bridge the gap between domestic saving and investment, on the other hand unbridled flows can fuel inflationary pressures, fan asset price bubbles, and sudden reversals in capital inflows can lead to instabilities and even crises in financial and currency markets. The decade of the 1990s was replete with several such incidents of financial crises all over the emerging world as seen in Mexico (1994), East Asia (1997), Russia (1998), Brazil (1999) and eventually Argentina (2000).

All these episodes of crises were triggered by rampant volatile debt inflows into the domestic economies. It is not surprising therefore that when its turn came after the crisis of 1991 India adopted a calibrated and hierarchical approach towards capital account liberalization, prioritizing some flows over others (Reddy, 2008). With the memories of the emerging economy crises fresh in mind, India gradually opened up non-debt flows (FDI, and portfolio) more than debt flows.

From early 2000s onwards India has been receiving significant amount of foreign investment. India experienced as many as three separate capital inflow surge episodes between 2000 and 2008 as analyzed by Sen Gupta and Sengupta (2015) using the methodology employed by Forbes (2014) to identify periods of capital surges and stops. This was the period when interest 
rates in the advanced world were relatively lower, emerging economies had started registering impressively high growth rates and their domestic macroeconomic fundamentals looked robust post recovery from the slew of financial crises of the 1990s, emerging economy central banks were also flush with foreign currency reserves and hence looked capable of defending any speculative attack on their respective currencies, and foreign investors in search of yields began investing massively in the equity and debt markets of the emerging world. India with an average growth rate of $9 \%$ and interest rates much higher than that of the advanced world was needless to say an attractive destination for these investors seeking higher yields. Net capital flows increased from $\$ 17.3$ billion in 2003-04 to over $\$ 107.9$ billion in 2007-08.

The pre-GFC surge episodes were primarily driven by bank and non-bank flows such as commercial borrowings by the Indian corporate sector, short-term trade credits and deposits by non-resident Indians as well as by portfolio equity flows. These inflows were encouraged by the widening interest rate differential between India and the advanced economies, greater liberalization of borrowing norms, improved domestic economy fundamentals and availability of abundant global liquidity. However, though in absolute terms India is now more open than it used to be during the early $1990 \mathrm{~s}$, the cautious and gradual approach towards capital account liberalization has meant that India has significantly lagged behind other countries irrespective of whether the capital account openness is measured using de-jure or de-facto indicators as shown by Sen Gupta and Sengupta (2013). Even today, more than two decades after India started opening up its capital account, there exists an extensive array of restrictive controls imposed by authorities on different categories of foreign investment in order to actively manage the capital account.

\subsection{Exchange rate management}

India officially moved to a market based exchange rate system in 1993Q3. Empirical analysis of the data shows that the nominal exchange rate has gone through several structural breaks since then. Zeileis, Patnaik and Shah (2010) and Patnaik, Shah, Sethy and Balasubramaniam (2011) show that while the Rupee was closely pegged to the dollar till 1997, during the Asian financial crisis of 1997-98, there was a short period of flexibility when the Rupee depreciated significantly. ${ }^{3}$ Thereafter from 1998 to 2004 the Rupee was once again tightly pegged to the Dollar. 2004 onwards the peg to the Dollar was replaced by a basket peg to several

\footnotetext{
${ }^{3}$ Here Dollar is used to imply the US dollar.
} 
other international reserve currencies such as Euro, Yen etc, implying that the exchange rate exhibited greater flexibility than before. The basket peg sort of ended around 2007 and gave way to a more flexible exchange rate regime that continued till 2013 July. In the summer of 2013 when the US Federal Reserve chairman Ben Bernanke announced a possible tapering of its Quantitative Easing (QE) program, large amounts of foreign capital fled India to safety driven by risk aversion thereby resulting in a sharp depreciation of the Rupee. The RBI intervened in the foreign exchange market in order to stabilize the Rupee and reduce the currency volatility.

Excessive foreign exchange intervention unless sterilized can fuel inflationary pressures by increasing the reserve money base. So in order to insulate the domestic economy from rising inflation central banks intervening in foreign exchange market to prevent a currency appreciation, conduct contractionary open market operations by selling bonds so as to absorb the excess liquidity from the system. The Rupee appreciated significantly in response to the surge in capital inflows from 2000 onwards thereby adversely affecting the competitiveness of Indian exports. During this time the RBI intervened actively in the foreign exchange market to prevent the Rupee from appreciating, given that India has had a long history of current account deficit and a nominal appreciation would have further aggregated the deficit. Till 2004 RBI sterilized this intervention by selling government bonds, raising the reserve requirements of the commercial banks by the concomitant amount and thereby reducing liquidity in the system.

RBI continued the sterilization till 2003 when it ran out of government bonds to sell. The Market Stabilization Scheme (MSS)- a new instrument for sterilization, was started around this time and RBI began issuing MSS bonds to sterilize its intervention but the rising fiscal costs of interest payment on bonds meant that sterilization could only be partial. This timing also happened to coincide with increased flexibility in the Indian rupee vis-à-vis the US dollar. Sen Gupta and Sengupta (2013) also find that RBI's intervention in the foreign exchange market has been sort of asymmetric, intervening when the exchange rate has been appreciating and adopting a hands off approach during times of depreciation, either for fear of losing reserves or to let a depreciating currency ameliorate a growing current account deficit.

The above discussion throws some light on where India stands with regard to capital account as well as exchange rate management. It seems India's capital account is only partially open and the exchange rate is in a managed floating regime. India has also been accumulating massive amounts of foreign currency reserves since the early 2000s. Foreign exchange reserves 
climbed from around $\$ 150$ billion in mid-2005 to over $\$ 300$ billion in mid-2010, a doubling in just five years and making India one of the largest reserve-holding countries in the world (Sen Gupta and Sengupta, 2013).

\section{Impossible Trinity or Trilemma}

The pioneering work in empirically assessing Trilemma as mentioned earlier, has been done among others, by Aizenman, Chinn and Ito (2010a, 2010b; 2011), henceforth referred to as ACI. They measured the Trilemma indices, namely monetary independence (MI), exchange rate stability (ERS) and capital account openness (KO) or financial integration over a large crosssection of countries - developed as well as developing. They also simultaneously incorporated the role played by foreign exchange reserves in macroeconomic management, which was quite a novel aspect, and hitherto not explored by others. ACI view reserves as a fourth dimension of these policy-trade offs. They find that most emerging economies operate in an intermediate range of partial financial integration and managed floating regimes with their respective central banks actively intervening in foreign exchange markets and using reserve management policies in the short-run to balance the trade-offs present by the Trilemma. Their seminal work in empirically measuring the Trilemma triggered a series of studies individually investigating evolution of the Trilemma for several emerging economies.

\subsection{Evolution of Trilemma in India}

Among the few empirical studies that have explored the issue of Trilemma in the Indian context, Hutchison, Sengupta and Singh (2011) were perhaps one of the earliest. In fact, it was also the first paper that took the ACI panel-data approach in measuring the Trilemma and modified it suitably to estimate the Trilemma in a time-series framework for a single country. In their paper they attempted to answer the questions: To what extent has financial integration imposed greater constraints on exchange rate and interest rate policies in India? What has been the cost of international financial liberalization in terms of macroeconomic policy?

They address these questions by measuring the trade-off between capital account openness (KO), exchange rate stability (ERS) and monetary independence (MI) in India. They calculate a Trilemma index for India and investigate its evolution over time. They also assess the impact of the Trilemma configurations on major macroeconomic indicators for India. 
They use quarterly data from 1996Q2 to 2009Q3 and therefore can exploit greater data variation unlike ACI who had used annual data. They also divide the entire sample period into three equal segments to better study the evolution of Trilemma over time. They measure MI as the reciprocal of the correlation between interest rates in the home country (here India) and the base country (here the United States). They calculate quarterly correlations using weekly interest rate data on 90-day government securities. More precisely, MI is measured as:

$$
M I=\frac{1-\operatorname{corr}\left(i^{\text {Ind }}, i^{U S}\right)}{1-(-1)}
$$

This index can theoretically take any value ranging from 0 to 1 with a higher value indicating greater degree of monetary independence. The authors measure ERS using quarterly standard deviations of the change in the log of Rupee-Dollar exchange rate and construct the index based on the following formula:

$$
E R S=\frac{0.01}{0.01+\operatorname{stdev}(\Delta(\log (\text { exch_rate }))}
$$

Appropriate scaling ensures that the index lies between 0 and 1, with the highest value indicating the greatest degree of exchange rate stability.

Finally, to measure financial integration Hutchison et al (2011) deviate significantly from ACI who use the de-jure Chinn-Ito index (Chinn and Ito, 2008), which for India exhibits little or no variation over time and hence might not be a suitable measure of capital account openness in the context of the Trilemma. Hutchison et al (2011) use a de-facto measure of capital account openness based on the ratio of the sum of inward and outward foreign investment flows to GDP (Lane and Milessi-Ferreti, 2007). Moreover, they use gross instead of net capital flows, in order to be able to distinguish between negligible flows and large flows. As pointed out succinctly by Sen Gupta and Sengupta $(2013,2014)$ as well, a country with high de jure openness can have low capital flows owing to limited opportunities for economic returns and hence be able to simultaneously stabilize exchange rate and retain monetary autonomy. Alternatively, a country with low de jure openness can experience large flows owing to low enforcement of capital 
controls, and face a trade-off between ensuring MI and ERS. The evolution of the three Trilemma indices during the sample period considered by Hutchison et al (2011) is presented in the three panels in Figure 1.

\section{Figure 1a: Monetary Independence Index}

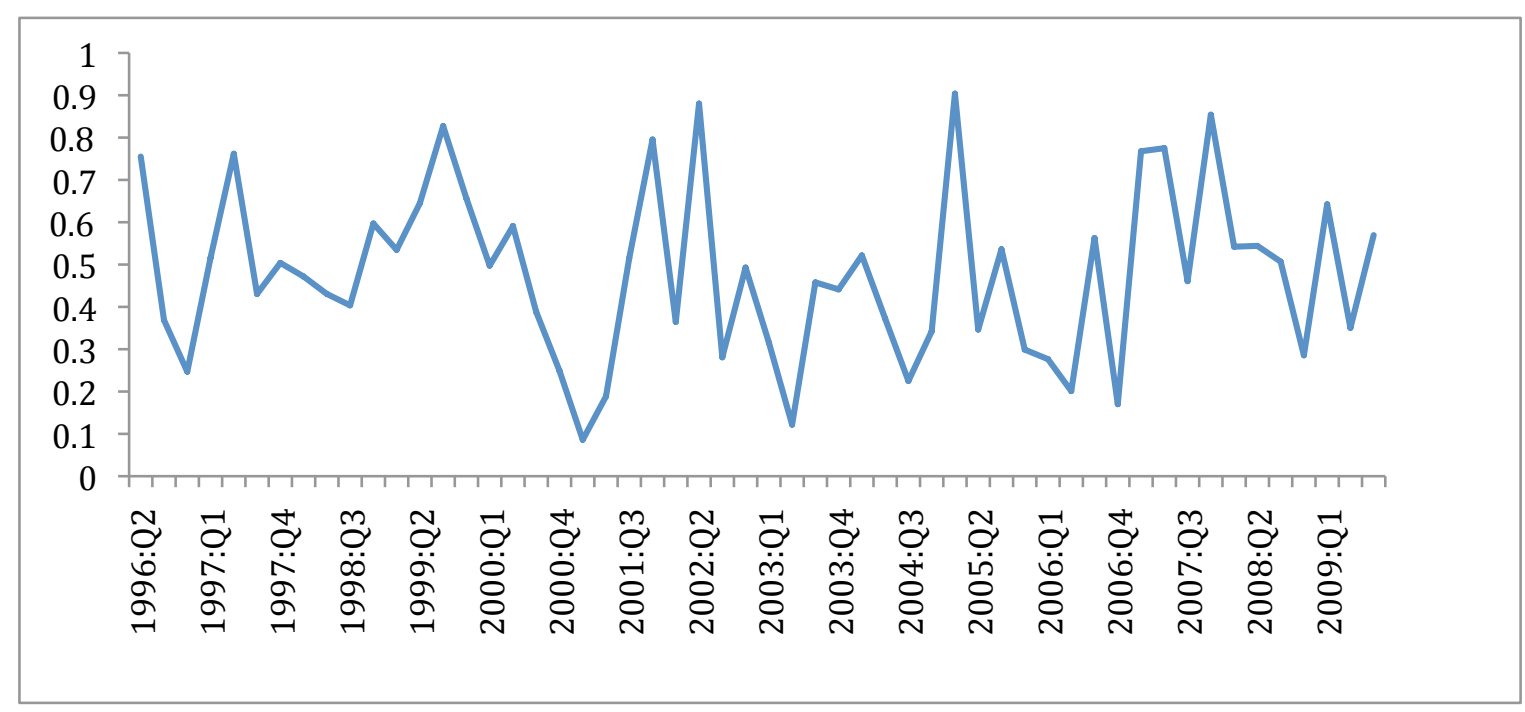

As mentioned before, an important contribution of ACI is connecting international reserves with the three Trilemma policy variables, the general idea being that reserve accumulation gives policymakers more flexibility in dealing with the short-run trade-offs between MI and ERS, for a given level of financial integration. Like other emerging economies, this is highly pertinent for India as well given the remarkable pace of reserve hoarding that the RBI has been undertaking especially since the early 2000s. In this context, Hutchison et al (2011) demonstrate the evolution of the Trilemma policy variables as well as of the reserves-GDP ratio for India over the three windows spanning across their sample period, using the classic diamond graph popularized by ACI. In the diamond graph the authors plot the averages of each of three Trilemma indices along with the reserves-GDP ratio for each sub-period. The diamond graph for India as seen in Figure 2 shows that the Indian economy increased its ratio of reserves to GDP along with greater financial integration, as it tried to balance MI and ERS. 
Figure 1b: Exchange Rate Stability Index

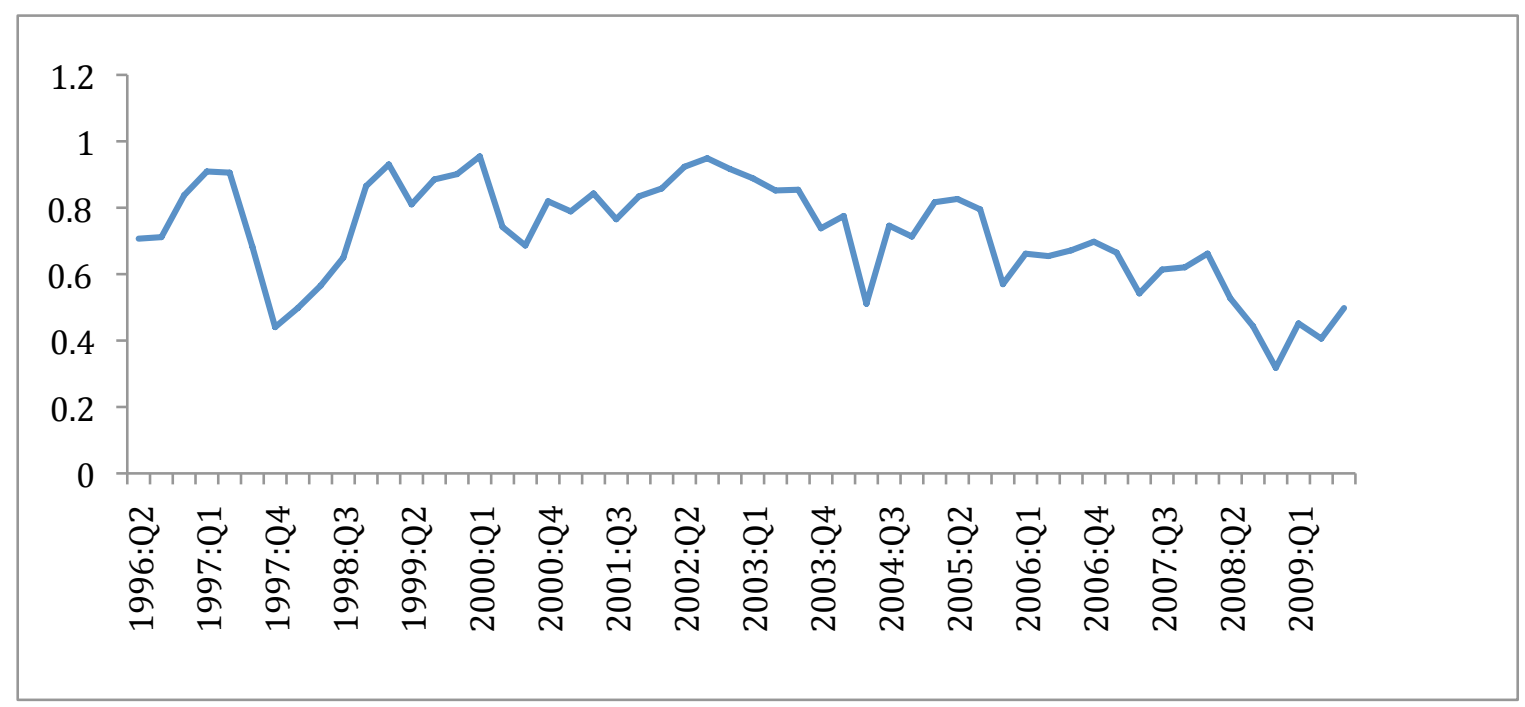

Figure 1c: Capital Account Openness Index

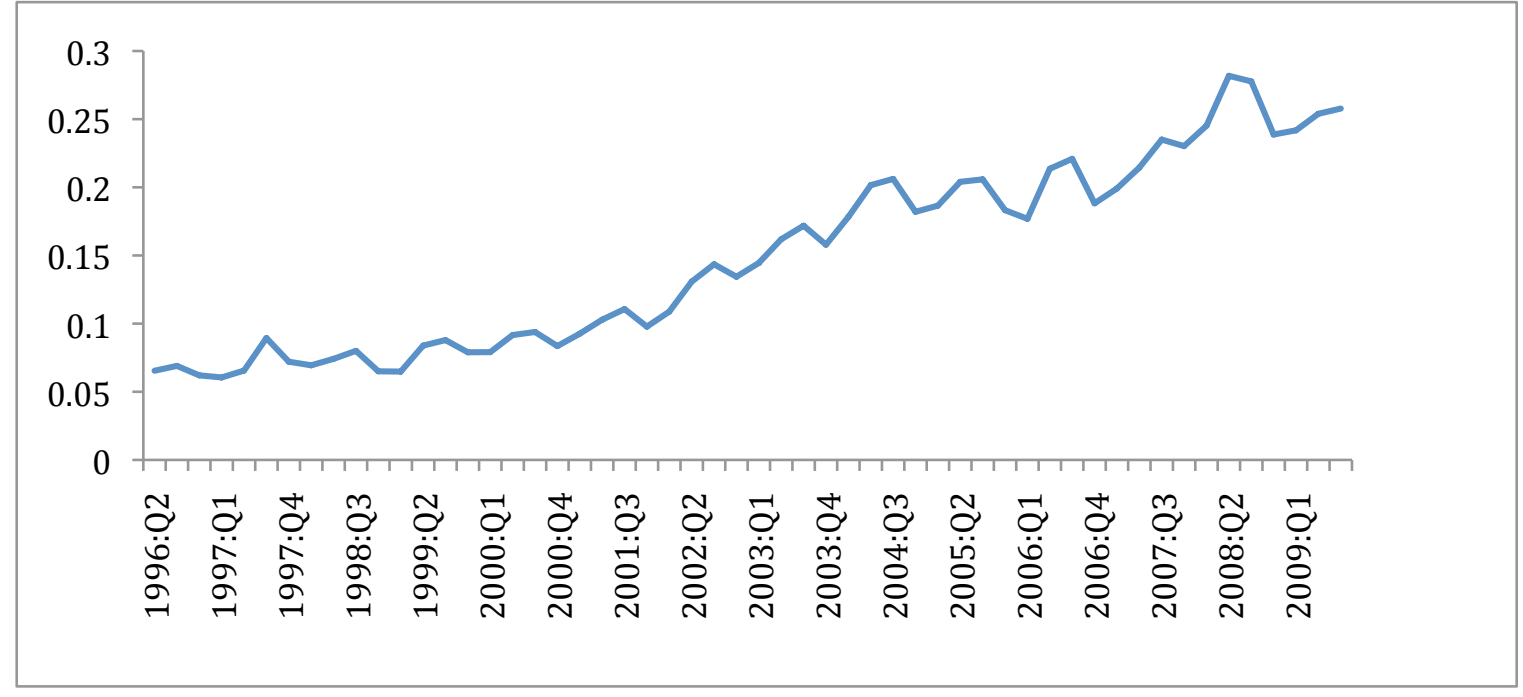

Source: Hutchison, Sengupta and Singh (2011) 
Figure 2: The Trilemma and Reserve Accumulation

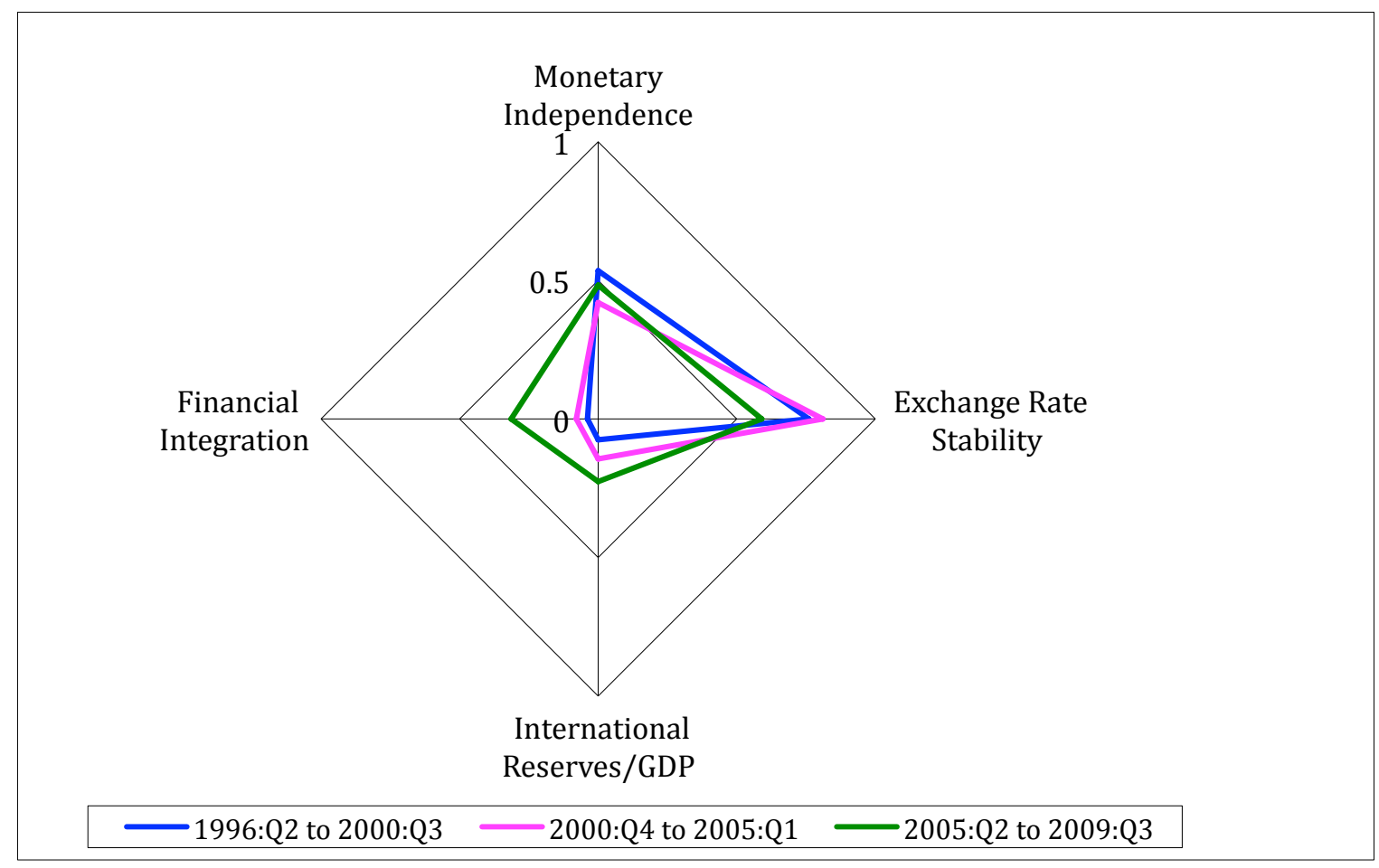

Source: Hutchison, Sengupta and Singh (2011)

While policy makers cannot achieve all three Trilemma objectives at the same time, they can always strive to achieve a combination of all three. With this principle in mind, the authors regress a constant (in their case, two) on the three indices and try to assess the relative weight placed by the Indian policy makers on each of the three policies. They find that ERS received high policy weight throughout their sample period. Between 2000Q4 and 2005Q1, as capital openness increased, MI was completely lost, whereas there was an attempt to retain, or even strengthen ERS. This was the phase of surge in capital inflows when the RBI was actively intervening in the foreign exchange market to prevent a nominal currency appreciation and stabilize the value of the Rupee vis-à-vis the Dollar. In the final sub period i.e. between 2005Q2 and 2009Q3, as capital openness continued to increase, some ERS was sacrificed to recover MI.

These findings match well with the facts presented in the previous section that post 2007 nominal exchange rate exhibited greater flexibility perhaps largely owing to inability of the RBI to fully sterilize its foreign exchange intervention. In general the authors find that as in other emerging countries, financial integration has increased markedly after the mid-2000s in India, which is also in line with the discussion in the previous section. The rise in capital account 
openness in turn, has come with corresponding limitations especially on MI. They also investigate the question how the change in the Trilemma configuration has influenced inflation and inflation volatility in India. The authors find that greater MI is empirically and systematically associated with lower inflation. On the other hand, greater ERS lowers inflation volatility, perhaps by stabilizing import and commodity prices. However, as India struggles to balance financial globalization with domestic monetary stability, capital account openness is found to be associated with higher inflation volatility.

In a later study empirically comparing the Trilemma evolution in China and India, Aizenman and Sengupta (2013) use a methodology similar to that of Hutchison et al (2011) over the period 1990Q1-2010Q4, and find that while China's Trilemma configurations are unique relative to other emerging markets in the predominance of ERS as a tool for macroeconomic management attained at the expense of MI and financial integration, in contrast, the Trilemma configurations of India seem more in line with the choices made by other emerging countries. India, like other emerging economies, has been balancing all three policy objectives and attaining a somewhat middle-ground perhaps through changes in its reserves stock, achieving comparable levels of ERS and financial integration. The authors find that ERS and financial integration were given marginally more importance followed by MI. In their rigorous econometric analysis, all three policy objectives come out statistically significant for India with relatively higher weight being placed on the ERS index, thereby echoing the findings of Hutchison et al (2011). Overtime the Trilemma configuration that has evolved in India is one of greater exchange rate stability and financial integration, combined with an attempt to retain monetary autonomy through active intervention in foreign exchange markets.

Finally, in their recent work Sen Gupta and Sengupta $(2013,2014)$ explore the various nuances of India's capital account management since the early 2000s. Among other things they also assess where India stands with respect to the open economy Trilemma and how the Trilemma has evolved over the time period 1996Q1 to 2011Q3. Resonating the findings of the previous studies in this domain, their empirical results also establish that instead of adopting corner solutions, India has embraced an intermediate approach in managing the conflicting objectives of the Trilemma, balancing the three policy objectives as per the demands of the macroeconomic situation. They use the same measures for MI and $\mathrm{KO}$ as the previous studies but for ERS they use a different methodology introduced by Frankel and Wei (1994). In their method, 
the degree of influence of major global currencies on the Indian Rupee can be estimated using the following model:

$\Delta \log \varepsilon_{I N R, t}^{C H F}=\alpha_{0}+\beta_{U S} \Delta \log \varepsilon_{U S D, t}^{C H F}+\beta_{E U R} \Delta \log \varepsilon_{E U R, t}^{C H F}+\beta_{J A P} \Delta \log \varepsilon_{J P Y}^{C H F}+\mu$

Here, $\varepsilon_{i, t}^{C H F}$ is the exchange rate of currency i against a numèraire currency, for which the authors use the Swiss franc and currency i can be the US Dollar, Japanese Yen and the Euro. If the Rupee is pegged to an individual or a basket of currencies the model will give a higher goodness of fit or $\mathrm{R}^{2}$. Accordingly, the authors estimate this model for each quarter using daily data and take the adjusted $\mathrm{R}^{2}$ as a measure of ERS, with a higher $\mathrm{R}^{2}$ indicating greater pegging to an individual or a basket of currencies. The evolution of this ERS series for the sample period considered by the authors is shown in Figure 3.

Figure 3: Exchange Rate Stability Index

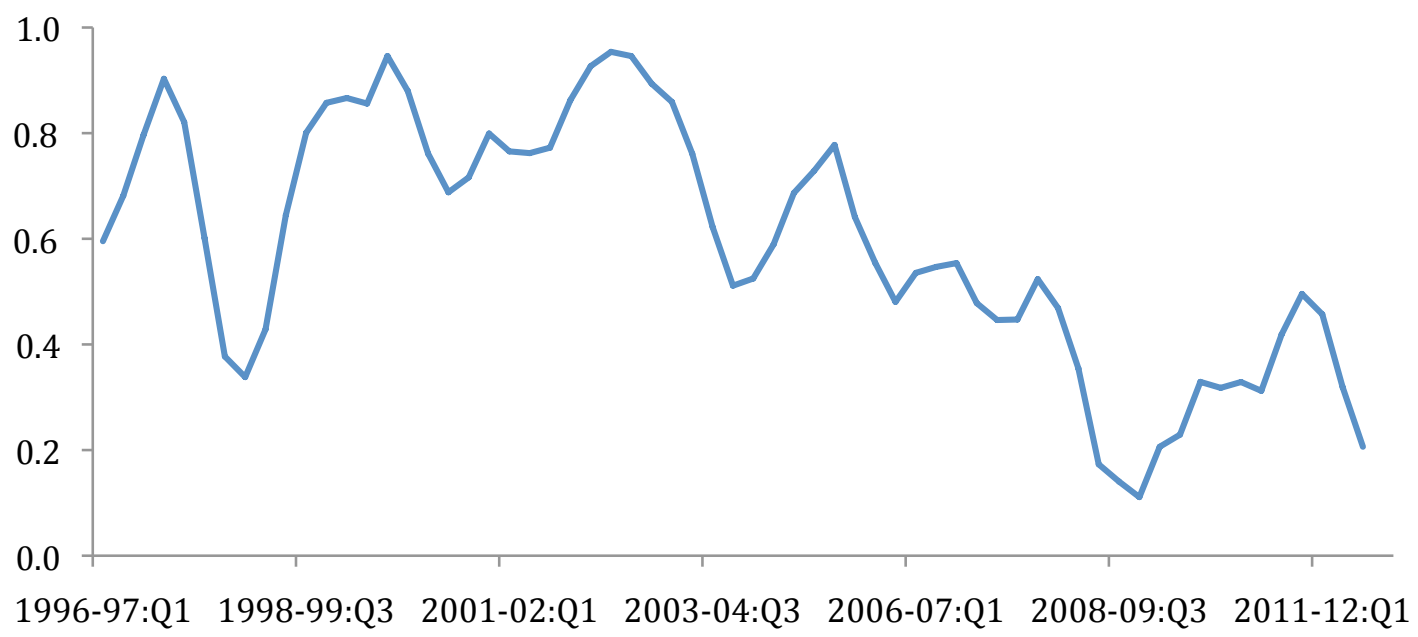

Source: Sen Gupta and Sengupta (2013). 
Figure 4: Configuration of the Trilemma Objectives and International Reserves

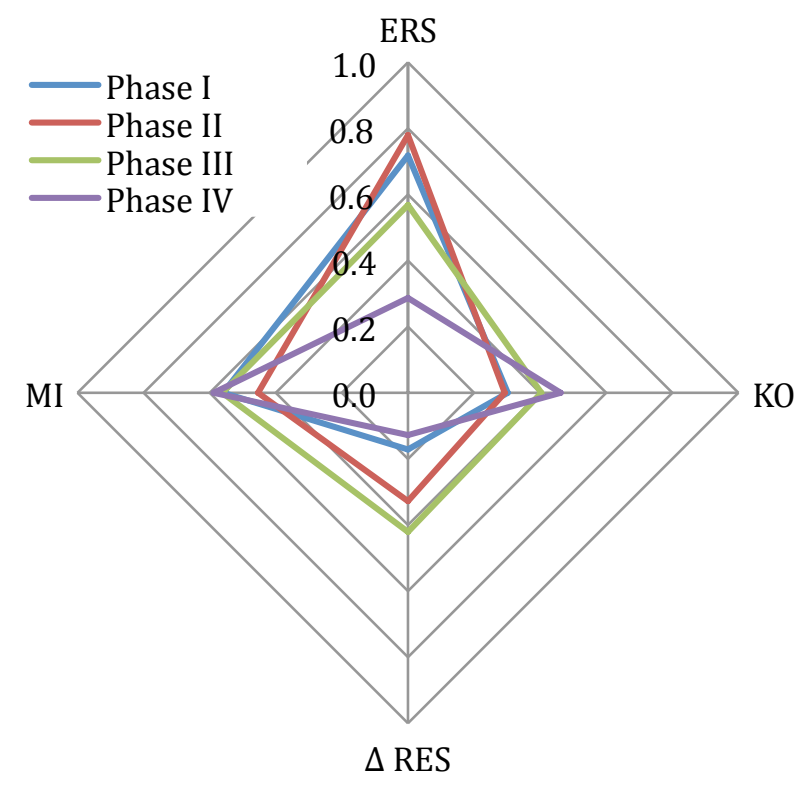

Source: Sen Gupta and Sengupta (2013)

The diamond chart from their study is shown in Figure 4 and demonstrates the evolution of the Trilemma very clearly over the period from 1996Q1 to 2011Q3, split between four equal time windows. During phases II and III i.e. from 2000Q1 to 20007Q4, RBI actively intervened in the foreign exchange market to prevent the Rupee from appreciating in the face of strong capital inflows. As mentioned earlier, while the RBI initially succeeded in sterilizing these interventions, from mid 2000s onwards rising fiscal cost of sterilization resulted in RBI only partially sterilizing its intervention, which in turn led to a reduction in monetary autonomy. In phase IV i.e. from 2007Q4 to 2011Q3, there was discernible shift towards greater MI balanced with greater flexibility of the exchange rate, which has acted as a shock absorber in a period of volatile capital flows.

Thus, while the previous studies have concluded that MI was notably compromised for the greater part of the 2000s in favor of greater ERS and financial integration, this study finds that MI has been substantially restored at the expense of ERS towards the end of the 2000s. This is perhaps because their study extends till 2011Q3 and from mid 2010 onwards RBI took recourse to significant monetary tightening policies in order to deal with rising wholesale price inflation. 


\section{Concluding remarks}

The rise in the volatility of global capital flows has made macroeconomic management increasingly complex especially for emerging economies that are striving to achieve a balance between the diverse objectives of robust growth rate, sustainable current account deficit, competitive exchange rate, access to adequate external capital for financing investment, moderate inflation, and sufficient international reserves. This has also reignited the debate on suitable macroeconomic management measures. One of the main challenges that emerging economies face today as they integrate with global capital markets is managing the trade-offs presented by the well known Impossible Trinity or open economy Trilemma and in this, India is no exception. The results of the few select empirical studies that have attempted to quantify the various policy objectives under the Trilemma in India summarized here seem to be overall consistent with those found for a broader group of emerging economies. Among this group the policy combination of exchange rate stability and financial openness has been the most dominant over the past two decades.

India seems to have actively managed its exchange rate, building up a high level of international reserves by intervening heavily in the foreign exchange market and has also managed to retain some control over domestic monetary policy. In fact, active intervention in foreign exchange market coupled with maintaining a reasonable degree of control over international capital flows seem to have emerged as a potent combination of policy instruments in India as it strives to manage the macroeconomic Trilemma. These issues are likely to be highly relevant in the current context in India as policy makers actively engage in inflation targeting to control domestic inflationary pressures, the Rupee exhibits renewed volatility in the face of foreign investment inflows and India strives to revive its erstwhile high growth rate. 


\section{References}

Aizenman, J., Chinn, M., and Ito, H. (2011) "Surfing the Waves of Globalization: Asia and Financial Globalization in the Context of the Trilemma," Journal of the Japanese and International Economies, Vol. 25, No. 3, p. 290-320.

Aizenman, J. and Sengupta, R. (2013) "The Financial Trilemma in China and a Comparative Analysis with India”, Pacific Economic Review, Vol.18, No. 2, p. 123-146.

Aizenman, J., (2010) “The Impossible Trinity (aka The Policy Trilemma)", in Encyclopedia of Financial Globalization (May).

Aizenman, J., Chinn, M., and Ito, H. (2010a) The Financial Crisis, Rethinking of the Global Financial Architecture, and the Trilemma," Asian Development Bank Institute Working Paper \#213 (April).

(2010b). "The Emerging Global Financial Architecture: Tracing and Evaluating the New Patterns of the Trilemma's Configurations", Journal of International Money and Finance, Vol. 29, No. 4, p. 615-641.

(2008). "Assessing the Emerging Global Financial Architecture: Measuring the Trilemma's Configurations over Time", NBER Working Paper No. 14533.

Chinn, M., and Ito, H. (2008), "A New Measure of Financial Openness", Journal of Comparative Policy Analysis, Vol 10 No. 3, pp. 307-320.

Forbes, K. J. (2014), "Capital Flow Volatility and Contagion- A Focus on Asia", in Managing Capital Flows: Issues in Selected Emerging Market Economies, (editors) Bruno Carrasco, Subir Gokarn, and Hiranya Mukhopdhyay, Oxford University Press.

Frankel, J. A., and Wei, S. J. (1994), "Yen Bloc or Dollar Bloc? Exchange Rate Policies of the East Asian Economies". in T. Ito and A.O. Krueger edited Macroeconomic Linkages: Savings, Exchange Rates, and Capital Flows, University of Chicago Press, p. 295-333

Hutchison, M., J. Kendall, G. Pasricha and N. Singh, 2012, "Effectiveness of Capital Controls in India: Evidence from the Offshore NDF Market," IMF Economic Review, Vol. 60, No. 3, p. 395438.

Hutchison, M., Sengupta, R., and Singh, N. (2011) "India's Trilemma: Financial Liberalization, Exchange Rates and Monetary Policy", The World Economy, Vol. 35, No. 1, p. 3-18.

Lane, P., and Milessi-Ferreti, G.M. (2007), “The External Wealth of Nations Mark II: Revised and Extended Estimates of Foreign Assets and Liabilities: 1970-2004", Journal of International Economics, Vol. 73 No. 2, p.223-250.

Mohan, R., and Kapur, M. (2009), "Managing the Impossible Trinity: Volatile Capital Flows and Indian Monetary Policy", Stanford Center for International Development Working Paper No. 401

Obstfeld, M., Shambaugh, J. C. and Taylor, A. M. (2005), "The Trilemma in History: Tradeoffs among Exchange Rates, Monetary Policies, and Capital Mobility", Review of Economics and Statistics, Vol. 87, No. 3, p. 423-38.

(2010), "Financial Stability, the Trilemma, and International Reserves", American Economic Journal: Macroeconomics, Vol. 2, No. 2, p. 57-94. 
Patnaik, I., Shah, A., Sethy, A., and Balasubramaniam, V. (2011), "The Exchange Rate Regime in Asia: From Crisis to Crisis", International Review of Economics and Finance, Vol. 20 Issue 3, p.32-43.

Reddy, Y.V. (2008), "Management of the Capital Account in India: Some Perspectives", Reserve Bank of India Bulletin, February.

Sen Gupta, A., and Sengupta, R. (2013), "Managing Capital Flows in India”, South Asia Working Paper Series, Asian Development Bank, No. 17.

(2014), "Negotiating the Trilemma and Reserve Management in an Era of Volatile Capital Flows in India", in Managing Capital Flows: Issues in Selected Emerging Market Economies, (editors) Bruno Carrasco, Subir Gokarn, and Hiranya Mukhopadhyay, Oxford University Press, pp. 1-34.

(2015). "Capital Flows and Capital Account Management in Selected Asian Economies", forthcoming CIGI Working Paper.

Shah, A., (2008), "New Issues in Indian Macro Policy", in T. N. Ninan, edited Business Standard India, Business Standard Books, Chapter 2, p. 26-54

Zeileis, A., Shah, A., and Patnaik, I. (2010), "Testing, monitoring, and dating structural changes in exchange rate regimes" Computational Statistics \& Data Analysis, Vol. 54, No. 6, p.16961706. 